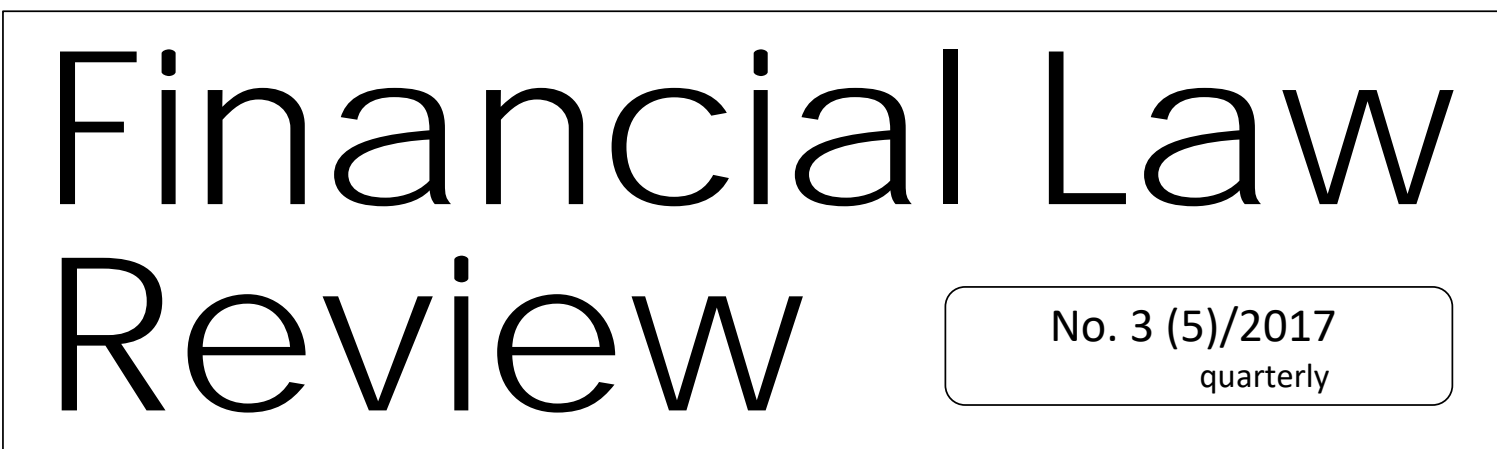

UNIVERSITY OF GDAŃSK • FACULTY OF LAW AND ADMINISTRATION http://www.ejoumals.eu • http://cza so pisma.bg.ug.edu.pl

\title{
LEGAL CONDITIONS LIMITING FUNDRAISING CAPABILITIES OF LOCAL SELF-GOVERNMENT UNITS. STATUS AND ORIGINAL PROPOSITIONS CONCERNING INTRODUCTION OF CHANGES TOGETHER WITH BANK GOSPODARSTWA KRAJOWEGO ${ }^{1}$
}

Sebastian Skuza*

\section{Abstract}

Reintroducing local self-governments in Poland was unquestionably a proper and necessary step in the transformation of the political and government system. Closing the civilization gap in municipal infrastructure will require a higher level of debt in local self-government units. Therefore, in practice

\footnotetext{
1 The article is a reprint of the article originally published in Finanse publiczne jednostek samorządu terytorialnego. Public Finance of Local Government, J. Gliniecka, E. Juchniewicz, T. Sowiński (ed.), CeDeWu Warszawa 2014

* Dr Sebastian Skuza, Katedra Systemów Finansowych Gospodarki, Zakład Bankowości i Rynków Pieniężnych, Wydział Zarządzania Uniwersytetu Warszawskiego.
} 
efficient development of local self-government units in the future is affected by amendments to legal provisions related to the capacity and level of debt. Despite their need for funding of infrastructure investments, local selfgovernment units rarely take advantage of public-private partnership. The Author of this paper believes that the perception of local public debt in Poland constitutes the justification of feasibility and necessity of implementing systemic changes, especially regarding limitations of local public debt. The purpose of this paper is to show the problems, which are caused by barriers related to limiting or assuming obligations or increasing fund management efficiency of local self-government units. Accepting solutions proposed by the Author would have a positive impact on the public finance sector, including the state budget and budgets of local self-government units. Such activities may therefore provide consolidation within one entity (Bank Gospodarstwa Krajowego) of management of bank accounts of local self-government units and increase of the capacity to raise funds, especially for infrastructure investments. Consolidation would have positive influence on short-term liquidity of local self-government units, while elimination of "qualitative" limitations and amendment of classification of expenses related to partially financing the PPP programme fees, would be more important in case of longterm fundraising for performing investment projects.

\section{Introduction}

Reintroducing local self-governments in Poland was unquestionably a proper and necessary step in the political transformation. Over fifty years of economic activities in Poland behind the "iron curtain" have caused a civilization gap, among others in the municipal infrastructure, which the local self-government units were unable to fill for almost 25 years of their existence. Due to the tendencies forming in Polish public finance sector, we cannot anticipate strong increase of self-government income; we also cannot count on transformation of its structure, i.e. replacement of a part of subsidies and grants with its own income, e.g. increase of revenue from real property tax by introducing cadastre or increasing share in direct and indirect taxes.

Closing the civilization gap in municipal infrastructure will require a higher level of debt in local self-government units. Therefore, in practice efficient development of local self-government units in the future is affected by amendments to legal provisions related to the capacity and level of debt. 
Despite their need for funding of infrastructure investments, local selfgovernment units rarely take advantage of public-private partnership.

The Author of this paper believes that the perception of local public debt in Poland constitutes the justification of advisability and necessity of implementing systemic changes, especially regarding limitations of local public debt. Securing proper funding in order to properly perform their duties is a much bigger problem for local self-government units. Before the Act on Public Finances of 26 November 1998 came into effect, the only limitations concerning the debt of local self-government units was the Act on Municipal Funding. Introducing new methods of financing local self-government units just to "evade" statutory limitations is simply an "art for art's sake" and de facto does not change the financial conditions of local self-government units.

The purpose of this paper is to show the problems, which are caused by barriers related to limiting or assuming obligations or increasing fund management efficiency of local self-government units.

The Author believes that taking into account the experiences from the performed consolidation process and subsequent efficiency growth regarding fund management in the public finance sector, as well as rational approach to assuming obligations by local self-government units, the three solutions presented below should be considered for implementation:

1. Consolidation of finances of local self-government units by Bank Gospodarstwa Krajowego.

2. Change in classification of expenses related to private partner fees concerning the performance of public-private partnership agreements.

3. Removal of certain qualitative limitations, which restrict local selfgovernment units' capacity to assume obligations.

In this paper the Author uses the following research methods: descriptive, analysis of empirical evidence using his own simulations.

\section{Consolidation of finances of local self-government units by Bank Gospodarstwa Krajowego.}


In accordance with Article 6, Paragraph 1 of the Act on Bank Gospodarstwa Krajowego of 14 March 2003, its scope of activities may include:

1) providing banking services for state budget accounts;

2) managing local self-government units' budgets;

3) managing national or self-governmental accounts of legal entities established on the basis of separate acts for the purpose of performing public tasks;

4) other activities set forth in separate acts;

5) other activities performed with the use of public funds, set forth in agreements concluded with government administration authorities.

The aforementioned provisions clearly state that Bank Gospodarstwa Krajowego may also assume the role of a public finance bank.

In accordance with Article 6, Paragraph 2 of the Act on Bank Gospodarstwa Krajowego of 14 March 2003, detailed scope of these activities are set forth in separate provisions and agreements concluded on their basis. Therefore, in order for Bank Gospodarstwa Krajowego to operate as a public finance bank, it is necessary to amend other acts, in particular the Act on Public Finances of 27 August 2009.

Amendment to the Act on Public Finances implemented by the government, i.e. the Act amending the Act on Public Finances and certain other acts of 16 December 2010, introduced the provision on consolidation of funds of a part of the public finance sector (chiefly of government administration) by Bank Gospodarstwa Krajowego.

In accordance with the implemented amendment, Article 78 of the Act on Public Finances of 27 August 2009, the Minister of Finance, acting on behalf of the State Treasury, has been authorized to receive available funds on deposit and to manage them for the purposes of financing the treasury borrowing requirements, as well as in relation with the management of the State Treasury's debt. Available funds are received on deposit by the Minister of Finance for an indefinite period of time. Executive agencies, the National Health Fund and other national legal entities established on the basis of separate acts are obliged to submit available funds to the Minister of Finance under civil law transactions. Remaining units of this sector, including local 
self-government units, will become members of this system (Article 264, Paragraph 3 of the Act on Public Finances of 27 August 2009).

One of the requirements for including the aforementioned units in the liquidity management system (mandatory and voluntary) is opening the account for a given unit at Bank Gospodarstwa Krajowego. Received and managed deposits of the public finance sector units are subject to interest rates. The interest rates were specified in accordance with the deposit period, e.g. 3 days, 3-6 days and over 7 days. Interest is governed mainly by the National Bank of Poland's deposit rate, Warsaw Interbank Bid Rate („WIBID”) and the multiplier, which cannot be lower than 0.9 [MarchewkaBartkowiak, 2010].

Bank Gospodarstwa Krajowego performs activities related to the reception of available funds by the Minister of Finance, submitted by certain public finance sector units on deposit or for their management and return, on the basis of the Act amending the Act on Public Finances and certain other acts of 16 December 2010 and the Minister of Finance Regulation of 15 April 2011 on available funds of certain public finance sector units, received by the Minister of Finance on deposit or for management as of 1 May 2011.

The Author believes that an analogous solution should also be implemented in the local self-government units sector, where dispersion of public funds is significant due to the amount of local self-government units and their autonomy.

Changes proposed by the Author would consist of amending Article 264 of the Act on Public Finances of 27 August 2009. Amendment of the aforementioned Article would assume that banking services for budgets of local self-government units should be exclusively provided by Bank Gospodarstwa Krajowego, however with the possibility of co-operation between Bank Gospodarstwa Krajowego and other national banks (e.g. by keeping auxiliary accounts) [Skuza, 2013].

Below, the Author presents his own project concerning provisions of Article 264, Paragraphs 1-4 of the Act on Public Finances of 27 August 2009:

Article 264. 1. Banking services for the budget of a local self-government unit shall be provided by Bank Gospodarstwa Krajowego - independently or upon agreements concluded with other national banks. 
2. Providing the service mentioned in Paragraph 1 shall be free of charge.

3. Provisions regarding the performance of banking services are specified by the agreement concluded between the administration of the local self-government unit and Bank Gospodarstwa Krajowego.

4. Entities, which constitute local self-government units may be authorized by the administration of such local self-government unit to invest available budgetary funds to accounts kept by banks other than Bank Gospodarstwa Krajowego in the form of a deposit submitted to the Minister of Finance, or to perform joint operations with Bank Gospodarstwa Krajowego in order to reduce the local self-government units' borrowing requirements or their costs.

5. The administration of a local self-government unit may take up loans in banks of its choosing, to the extent of authorizations specified in the budget resolution, in accordance with provisions on public procurement.

6. Granting a power of attorney to manage the bank account of the local selfgovernment unit is prohibited in order to maintain credit or loan security.

The mechanism proposed by the Author assumes mandatory collection of basic accounts of local self-government units at Bank Gospodarstwa Krajowego, which would facilitate e.g. monitoring and may result in benefits regarding the public finance sector's debt and sources of financing. Other than maintaining the local self-government units' budgets, Bank Gospodarstwa Krajowego could also assume the role of an intermediary (agent) procuring the so-called short-term financing for respective local selfgovernment units using funds of other local self-government units with excess balance. Such activities would limit the growth of national public debt on the self-government level. Temporary excess funds of local self-government units could be also used to finance the state's borrowing requirements.

Furthermore, in the event of placing all funds of local self-government units (accounts and deposits) in the hands of Bank Gospodarstwa Krajowego, the Bank could offer each local self-government unit individual and flexible credit loans, which would allow local self-government units to repay loans of any kind using owned deposits.

By the end of 2013, local self-government units held PLN 13.1 billion on accounts and deposits in banks, while the amount of debt concerning loans and bonds was equal to PLN 50.2 billion, furthermore, most of the units were 
encumbered by loan obligations and held significant deposits at the same time. Obligations of local self-government units could be partially consolidated - part of loans could be repaid using excess funds on deposits provided that appropriate instruments would be granted to the units. It would decrease debts of self-governments and, as a result, decrease the public debt as well as self-governments' expenses (debt service costs).

The variant of consolidation described below assumes that the repayment takes place by taking up a new consolidation loan for each local selfgovernment unit up to the maximum value of $7.5 \%$ of income. The calculations utilize data as at 2013; the calculations do not take reduction of debt service costs into account. This variant considers the situation, in which all funds of local self-government units (accounts and deposits) are placed in the hands of Bank Gospodarstwa Krajowego, which would offer each local self-government unit a consolidation loan up to the maximum value of $7.5 \%$ of income. Local self-government units could then repay loans using owned deposits, however in the amount not exceeding $7.5 \%$ of income. In such case, the consolidation would only proceed individually for each local selfgovernment unit.

Table 1. Effect of consolidation of obligations and payables of local self-government units using a consolidation loan at BGK (in millions of PLN)

\begin{tabular}{|l|r|r|r|r|r|}
\hline & \multicolumn{2}{|l|}{ before the consolidation } & \multicolumn{2}{l|}{ after the consolidation } \\
\cline { 2 - 6 } & receivables & obligations & receivables & obligations & $\begin{array}{l}\text { effect } \\
\text { of the } \\
\text { consolidation }\end{array}$ \\
\hline Communes & 5,752 & 22,334 & 2,517 & 19,100 & $-3,234$ \\
\hline $\begin{array}{l}\text { Cities with district } \\
\text { rights }\end{array}$ & 4,476 & 18,317 & 1,560 & 15,401 & $-2,916$ \\
\hline Districts & 1,549 & 5,638 & 348 & 4,437 & $-1,201$ \\
\hline Provinces & 1,285 & 3,870 & 375 & 2,961 & -910 \\
\hline TOTAL & 13,061 & 50,160 & 4,799 & 41,898 & $-8,262$ \\
\hline
\end{tabular}

Source: [analyses by T. Kaczor, M. Michniewicz, based on the Author's concept]

Effects of the consolidation could be stronger in case of consolidation of payables and obligations between local self-government units, for which Bank Gospodarstwa Krajowego could act as intermediary (manager) for such transaction. 


\section{Terms of qualification of expenses due to public-private partnership agreements by local self-government units}

In the biggest EU countries, i.e. the United Kingdom, France, Italy, publicprivate partnership („PPP”) constitutes a basic mechanism of financing investments for key infrastructures - municipal in this case. In these countries, significant amount of PPP projects became possible due to comprehensive actions of governments, which deemed PPP as the most effective mechanism for performance of significant infrastructural projects. PPP programs adopted at the national level are characterized by precise and transparent terms of risk allocation between partners, which helps a large number of strategic and financial investors to take part in the development of the infrastructure. Poland, despite observing legal provisions supporting PPP, in the vast majority of cases uses traditional investment financing systems for performances of municipal infrastructure projects [Recommendations, 2014].

Without religiously defining PPP as the only possible method of performing national infrastructure investments, we have to act in order to find solutions, which would allow the growth of PPP in Poland, especially in local selfgovernment units.

Article 243 of the Act on Public Finances of 27 August 2009 specifies the method of calculating the individual debt index of local self-government units. This index is significantly influenced by the method of qualification concerning budgetary expenses of local self-government units under PPP projects (on-going or capital expenses). Regarding the relationship between on-going and capital expenses, the Act on Public Finances introduced two important - in the context of PPP projects - provisions:

1) balancing of on-going expenses with on-going budgetary income (Article 242 of the Act on Public Finances of 27 August 2009) - which provisions remains in force as of the beginning of 2011 ;

2) individual debt limit (Article 243 of the Act on Public Finances of 27 August 2009) - which remains in force as of 1 January 2014.

Individual (maximum) debt limit shall be calculated using the arithmetic average from the relationship between on-going income increased by income from property sales and reduced by on-going expenses and the total budget income. Three financial years shall be used to calculate this average, which means that even as of 2011 obligations of self-governments under PPPs, 
which are included in the public debt, influence the individual debt limit. The aforementioned provisions reduce the attractiveness of PPP projects from the point of view of local self-government units.

Considering the possibility of amending the Act on Public Finances regarding the terms of local self-government units' qualification of expenses related to the private partner's remuneration, i.e. including such expenses in capital expenses. Therefore, the Author believes, that Article 236, Paragraph 4 of the Act on Public Finances of 27 August 2009 shall be amended by adding a fourth item, which states that the capital expenses also include expenses related to the private partner's remuneration for the performance of tasks under public-private partnerships.

The Author describes his own project concerning provisions of Article 236, Paragraph 4 of the Act on Public Finances of 27 August 2009 below:

Article 236. 4. Capital expenses plan, in its distribution according to sections and chapters, capitalizes planned amounts of capital expenses, which include expenses for:

1) investments and investment purchases, including programs financed using funds mentioned in Article 5, Paragraph 1, Items 2 and 3, in part concerning performance of the local self-government unit's tasks;

2) purchase and subscription of stocks and shares;

3) paying contributions to commercial law companies;

4) expenses related to the private partner's remuneration for the performance of tasks under public-private partnerships.

In case of such investment projects implemented under PPP by local selfgovernment units, Bank Gospodarstwa Krajowego could additionally act as institution certifying projects in accordance with their bankability. In France, such role is filled by Mission d'Appui à la Réalisation des Contrats de Partenariat („MAPPP”).

MAPPP is an inter-ministerial body, administratively related to the Ministry of Finance and Economy and acting on behalf of the whole public sphere. It fills the role of a national expert organization, the purpose of which is to serve both national and self-government units, as well as other entities interested in implementing PPP projects, including PPP project assessment on the 
preparatory stage with regard to the correctness of used procedures and financial settlements. MAPPP, as a national expert organization, is obliged to analyse and submit opinion on projects planned for implementation by governmental entities.2. MAPPP's main tasks include [Ministry of Economy, 2013]:

1) planned PPP project analysis in their preliminary phase (verification of compatibility with legal provisions and meeting 3 requirements: urgency, complexity, efficiency, preliminary financial and economic analysis, verification of feasibility and justification of implementation of the project using the PPP formula);

2) promotion of PPP partnerships and public partners;

3) verification and submitting opinions on legislation and other aspects related to PPP;

4) being a part of the committee, which issues government-backed guarantees for PPP projects.

MAPPP, after performing the analysis and issuing suitable opinion for PPP projects planned by governmental institutions, submits such information to the Minister of Finance, who makes the final decision on approving the project for implementation using the PPP formula. MAPPP performs all aforementioned tasks free of charge. It is made up of 9 people, experts from areas of the public sector with experience in the business sector or in financial institutions.

\section{Removal of certain qualitative limitations, which restrict local self-government units' capacity to assume obligations}

Regarding the limitations on assumption of municipal obligations, it is worth noting that the Act on Public Finances of 26 November 1998, besides "quantitative" limitations also introduced "qualitative" limitations, which still remain in force in almost identical form. The aforementioned solutions limit maximum discounting issued by local self-government units for securities to $5 \%$ of the nominal value (Article 92 of the Act on Public Finances of 27 August 2009). This provision was unquestionably introduced in order to limit

\footnotetext{
${ }^{2}$ Projects implemented on the self-governmental level do not have to be analysed by MAPPP. They are only verified upon request.
} 
possible accumulation of payments. Similar ratio legis was granted after introduction of a provision on the lack of possibility of interest compounding for self-governmental obligations. It is not clear why local self-government units could not issue securities solely on the basis of financial capabilities and profitability of the project in comparison to other forms of debt. The Author believes that any and all forms of debt of local self-government units should be regulated exclusively by acts related to the given type of security (e.g. Act on Bonds).

Furthermore, local self-government units, in accordance with Article. 93 Paragraph 1 of the Act on Public Finances of 27 August 2009, cannot take on a loan or credit, issue securities or grant sureties or guarantees, the nominal value of which payable on the due date, specified in PLN, was not specified on the day of entering into the transaction. In practice, this means that there is no way to assume currency obligations. In the assessment of the Author, amendment of the Act on Public Finances with the purpose of correcting the provisions of the act in order to allow local self-government units to assume foreign currency obligations is legitimate. As of 12 April 2000, the PLN exchange rate has been made flexible and even natural persons are not limited regarding collection of currencies on foreign accounts and assumption of obligations. There is no justification for keeping local self-government units „sheltered" concerning PLN obligations within the current economic system. Currency risk is an integral part of economic processes, which may be limited by performing specific ativities, but cannot be completely avoided.

Below, the Author presents his own project concerning provisions of Article 92 and Article 93 of the Act on Public Finances of 27 August 2009:

Article 92. 1. Local self-government units may only assume obligations with the purpose mentioned in Article 89, Paragraph 1, Items 2-4 and Article 90, for which the service costs are charged at least once a year.

2. Limitation mentioned in Paragraph 1 is applicable respectively to the public finance sector units other than the State Treasury.

Article 93. 1. Public finance sector units, excluding the State Treasury and local self-government units, may not issue securities or grant sureties and guarantees, the nominal value of which, payable on the due date, specified in PLN, was not specified on the day of entering into the transaction. 
2. The Council of Ministers shall specify in a Regulation cases, which are exempt from limitations mentioned in Paragraph 1, taking into account the characteristics of credits and loans from international institutions or governmental subcontractors, as well as the capacity to perform the assumed obligations and limiting the growth of the national public debt level.

\section{Conclusion}

In Poland, the liquidation management system is predominantly applicable to the governmental administration bodies, which are obliged to temporarily submit available funds for the Minister of Finance to manage. It means that there is an option to support liquidity in cases of short-term fund deficits [Marchewka-Bartkowiak, 2010].

Accepting solutions proposed by the Author would have a positive impact on the public finance sector, including the state budget and budgets of local selfgovernment units. For such activities may provide consolidation of management of bank accounts of local self-government units within one entity (Bank Gospodarstwa Krajowego) and increase the capacity to raise funds, especially for infrastructure investments. Consolidation would have positive influence on short-term liquidity of local self-government units, while elimination of "qualitative" limitations and amendment of classification of expenses related to partially financing the PPP programme fees would be more important in case of long-term fundraising for performing investment projects. The Author is aware of the possibility of critique from the enthusiasts of limiting the capacity to assume obligations by local selfgovernment units, thus limiting national public debt. It is worth noting, however, that the correctness of the Author's reasoning may be confirmed by the example of French solutions. Financial difficulties of French local selfgovernment units in the beginning of 1990s were not met with increased sanctions and limitations by the legislative and regulatory government bodies. Moreover, reorganization of insolvent local self-government units was based predominantly on renegotiations of terms of repayment of each obligation and support from the government in form of temporary increase of such local 
self-government unit's income. When respective local self-government units suffered financial problems, the French government strengthened monitoring of French local finances. Bank Gospodarstwa Krajowego seems to be a natural partner for the government and regional accounting chambers regarding the strengthening of monitoring of financial conditions of Polish local selfgovernment units. 